\title{
Assessment of Water Quality of Kolpu Khola in Sisdol Landfill Area of Nuwakot District
}

\author{
Ujjwal Thapa Shrestha $^{1}$, Jaya K. Shrestha ${ }^{2}$ and Rohini P. Devkota ${ }^{1}$ \\ ${ }^{1}$ Central Departments of Environmental Science, Tribhuvan University, Kathmandu, Nepal \\ ${ }^{2}$ Central Department of Chemistry, Tribhuvan University, Kathmandu, Nepal \\ e-mail: ujjwalts2007@gmail.com
}

\begin{abstract}
The present study was carried out to determine the impact of the leachate contamination on water quality of Kolpu Khola nearby Sisdol landfill site. Water samples were collected from six different sites of Kolpu Khola from upstream to downstream. The samples were collected in clean plastic bottles from a leachate collection from December, 2007 to August, 2008 and analyzed for the determination of physical parameters (pH, conductivity, temperature) and chemical parameters (dissolved oxygen, alkalinity, chloride, calcium hardness, total hardness, $\mathrm{BOD}_{5}, \mathrm{PO}_{4}-\mathrm{P}, \mathrm{NO}_{3}-\mathrm{N}, \mathrm{NH}_{4}-\mathrm{N}$ ) using a standard method. It was found that leachate was severely polluted with most of the physicochemical parameters being higher than the generic standard for industrial effluent discharged into inland surface water. The variation of BOD and COD showed that the chemistry of the leachate in the landfill was undergoing rapid change. The surface water of Kolpu Khola was not polluted from chloride point of view and the spatial variation of chloride content was significant at 0.01 significance level. The river water at all the sites under study had $\mathrm{PO}_{4}-\mathrm{P}$ above natural range i.e. 0.005 to $0.020 \mathrm{mg} / \mathrm{l}$ and was not suitable for livestock drinking and for aquatic animals with reference to most of the physicochemical parameters studied.
\end{abstract}

Key words: leachate, Sisdol sanitary landfill, solid waste

\section{Introduction}

Water is integral part of the environment and is of vital importance to all socio-economic sectors. About $70 \%$ of the earth's surface is covered with water but the supply of freshwater is limited in the global level and governed by the renewal processes associated with the global hydrological cycle. Water pollution is any physical, chemical or biological change in water quality that has a harmful effect on living organism or makes water unsuitable for desired uses (Miller 2002). In Asia and the Pacific region, water supply is a serious problem. Already at least one in three Asians has no access to safe drinking water and freshwater will be the major limiting factor to producing more food in the future (UNEP 1999). Improper disposal of solid waste is one of the reasons of water pollution.

Solid waste is useless and sometimes hazardous material with low liquid content (OECD 2008). Solid waste is an inevitable by-product of human activities.
At all levels of socio-economic development, human beings produce solid waste. The production of solid waste is closely linked with the human behaviour and attitudes. Due to change in the economic and consumption pattern of the people resulted by urbanization, the amount of wastes has been increased causing environmental problems.

Sanitary landfill is an engineered facility for the disposal of municipal solid waste designed and operated to minimize public health and environmental impacts. The Sisdol landfill site (SLFS) is semi-aerobic landfill and has been selected for short-term operation with an objective to develop the Okharpauwa site for long-term operation. It has been in operation for the disposal of solid wastes of Kathmandu Metropolitan city and Lalitpur Sub-metropolitan City. The SLFS is full and Aletar Landfill Site has been constructed at Aletar-4 in Okharpauwa of Nuwakot for a short-term garbage dumping site. 
The most prevalent form of disposal of solid waste is by dumping the waste into a sanitary landfill. Unfortunately, sanitary landfills are not ideal for the disposal of solid waste. When rain water percolates through a pile of solid waste, it picks up the soluble materials with it. The resulting contaminated water is called leachate which contains dissolved inorganic and organic solutes. In course of time, the leachate diffuses into the soil and changes the physicochemical characteristics of water. Some of the pollutants may be adsorbed on to the soil media during the flow of leachate through the soil. Leachate contains different chemicals that are harmful to human health. Therefore leachate represents one of the most significant environmental problems in the design and maintenance of landfills. The characteristics of municipal landfill leachate vary greatly within an individual landfill over space and time. Also, the leachate characteristics vary considerably from one landfill to another (Leckie et al. 1979, Kouzeli-Katsiri et al. 1999).

The objective of the study was to analyse the physicochemical parameters of leachate and surface water of Kolpu Khola and to determine the monthly/ seasonal and spatial (upstream to downstream) variation of the parameters

\section{Description of study area}

The Sisdol sanitary landfill site is situated between latitude $27^{\circ} 46^{\prime} 00^{\prime \prime}$ to $27^{\circ} 46^{\prime} 30^{\prime \prime} \mathrm{N}$ and longitude $85^{\circ}$ $14^{\prime} 30^{\prime \prime}$ to $85^{\circ} 15^{\prime} 30^{\prime \prime} \mathrm{E}$ in Nuwakot district, which is bordered by Kolpu Khola to the south from Dhading district and to the southeast from Kathmandu district. The SLFS is a semi-aerobic landfill and is about $18 \mathrm{~km}$ NW from Kathmandu city center (SWMRMC 2005) and about $28 \mathrm{~km}$ far from Teku Transfer station.

The SLFS has warm subtropical climate characterized by heavy monsoon rainfall occurring between June to September and delivering a total annual average rainfall of $2990 \mathrm{~mm}$ (1990). This figure is based on Kakani rainfall station, which may vary with rainfall at the bottom of the hill (at Kolpu Khola basin). At Okharpauwa (the bottom of depression of the hills) the average temperature is $21^{\circ} \mathrm{C}$ with a maximum and minimum temperature of $41^{\circ} \mathrm{C}$ and $4^{\circ} \mathrm{C}$ respectively (SWMRMC 2005).

The landfill system in Sisdol is an appropriate adoption of the so-called "Fukuoka Method" of semi-aerobic type. In this method the leachate collected in the pond is regularly aerated through proper aerator system, which can be regarded as biological aerobic treatment. The aerated leachate is further recirculated by means of a pump to spray the leachate over landfill cells for a simple anaerobic biological treatment. The integration of these two processes results in significant improvement in the leachate quality (JICA 2004).

\section{Methodology \\ Sample collection}

The sampling sites of Kolpu Khola were selected on the basis of a reconnaissance survey throughout the river from the confluence of Thulo Khola and Kolpu Khola up to Jyamire Kholso. The sampling sites in the Kolpu Khola were fixed by the confluence of rivers and rivulets joining into the river. A reference site at upstream of the river was taken for facilitating the comparative study of the water quality obtained during the study. Other sites in the river were either in the immediate downstream, upstream of the confluence of the river or leachate discharge site.

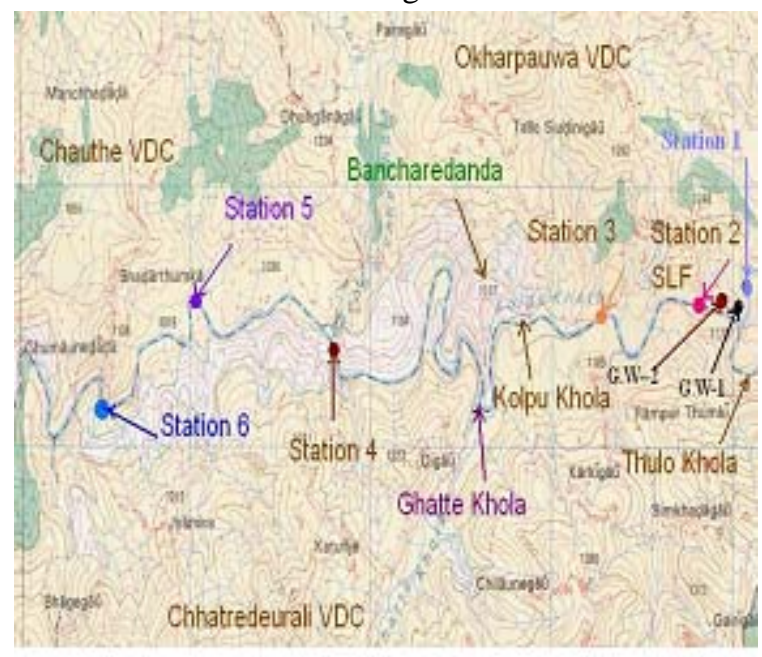

Fig. 1. Map showing surface water sampling sites

All together 7 samples were collected- 1 sample from leachate tank, 6 samples from the Kolpu Khola at various distances from the landfill. The sampling site 1 was located behind the bridge at about a distance of about $300 \mathrm{~m}$ upstream from the point of confluence of Thulo Khola and Kolpu Khola. The sampling site 2 was located about $30 \mathrm{~m}$ downstream from the confluence of Thulo Khola and Kolpu Khola. At this point leachate that came from leakage from the landfill got mixed into the Kolpu Khola. The sampling site 3 
Ujjwal Thapa Shrestha et al./Assessment of Water Quality ......

was located on the way to Banchare Danda at a distance of about $1 \mathrm{Km}$ from the confluence of Thulo Khola and Kolpu Khola. The sampling site 4 was located just before the confluence of Kolpu Khola and Bachhbichhe Khola. It lied at a distance of approximately $4.4 \mathrm{Km}$ from the confluence of Thulo Khola and Kolpu Khola. The sampling site 5 was just before the confluence of Khole Khola and Kolpu Khola. The sampling site 6 was just upstream of the confluence of Jyamire Khola (rivulet) and Kolpu Khola. Except site 1 and 2 other sampling sites were chosen at the confluences of the river (site 3 ) or before (site 4 , site 5 and site 6) the confluences of the river to estimate the pollution level before and after the mixing of water from tributaries of Kolpu Khola.

The type of sample taken was grab sample. Samples were collected in clean plastic bottles. Before sampling, the sample bottles were rinsed three times with river water. The sampling bottles were dipped at approximately $10-20 \mathrm{~cm}$ below the water surface, projecting the mouth of the bottle against the flow direction. Water samples for analysis of ammoniacalnitrogen was preserved by adding conc. $\mathrm{H}_{2} \mathrm{SO}_{4}$ (to maintain $\mathrm{pH}$ less than 2). The samples were transported within $24 \mathrm{hr}$ to the Central Department of Environment Science and refrigerated $\left(<4^{\circ} \mathrm{C}\right.$ but above freezing $)$

Table 1. Methods used for analysis of physicochemical parameters

\begin{tabular}{|c|c|}
\hline Parameters & Methods \\
\hline $\begin{array}{ll}\text { 1. } & \mathrm{pH} \\
\text { 2. } & \text { Elec tric al conductivity }\end{array}$ & $\begin{array}{l}\text { Potentiometric me thod } \\
\text { Potentiometric me thod }\end{array}$ \\
\hline $\begin{array}{l}\text { 3. Dissolved Oxygen } \\
\text { (D } O \text { ) }\end{array}$ & $\begin{array}{l}\text { Winklers Iodometric } \\
\text { method }\end{array}$ \\
\hline 4. Chloride & Argentometric method \\
\hline 5. Total alkalinity (T.A.) & Titrimetric method \\
\hline $\begin{array}{l}\text { 6. Orthophosphate } \\
\left(\mathrm{PO}_{4}-\mathrm{P}\right)\end{array}$ & $\begin{array}{l}\text { Amrnonium } \\
\text { molybdate me thod. }\end{array}$ \\
\hline $\begin{array}{l}\text { 7. Hardnes and calcium } \\
\text { hardnes }\end{array}$ & EDTA method \\
\hline 8. Calcium & EDTA method \\
\hline $\begin{array}{l}\text { 9. Nitrate-nitrogen } \\
\left(\mathrm{NO}_{3}-\mathrm{N}\right)\end{array}$ & $\begin{array}{l}\text { Phe nol disulforic } \\
\text { method }\end{array}$ \\
\hline $\begin{array}{l}\text { 10. Biological } \\
\left.\text { oxygen de mand ( } \mathrm{BOD}_{5}\right)\end{array}$ & Titrimetric method \\
\hline $\begin{array}{l}\text { 11. Che rucal oxygen } \\
\text { demand (COD) }\end{array}$ & Titrimetric method \\
\hline $\begin{array}{l}\text { 12. Armmoniacal } \\
\text { nitrogen }\left(\mathrm{NH}_{4}-\mathrm{N}\right)\end{array}$ & Phe nate method \\
\hline 13. Total iron & $\begin{array}{l}\text { Phe nanthroline } \\
\text { method }\end{array}$ \\
\hline
\end{tabular}

\section{Analysis of physical and chemical parameters}

The physical and chemical parameters were analysed using standard method (APHA 1995). The physical parameters ( $\mathrm{pH}$, conductivity, temperature) and chemical parameters (DO, alkalinity, chloride, calcium hardness and total hardness) were measured in situ. The $\mathrm{BOD}_{5}, \mathrm{PO}_{4}-\mathrm{P}, \mathrm{NO}_{3}-\mathrm{N}$ and $\mathrm{NH}_{4}^{-}$ $\mathrm{N}$ were analysed in the laboratory.

The $\mathrm{pH}$ of water samples was measured using $\mathrm{pH}$ meter (Model HI 8314 portable pH meter with accuracy \pm 0.01 at $20^{\circ} \mathrm{C} / 68^{\circ} \mathrm{F}$ ) and the conductivity was measured using calibrated (with standard potassium chloride solution of $0.01 \mathrm{~N}$ ) conductivity meter of Model 4150 (with accuracy of $0.5 \% \pm 2$ digits). For the measurement of orthophosphate $\left(\mathrm{PO}_{4}-\mathrm{P}\right)$, ammoniacal- nitrogen $\left(\mathrm{NH}_{4}-\mathrm{N}\right)$, nitratenitrogen $\left(\mathrm{NO}_{3}-\mathrm{N}\right)$ and iron content of water, Spectrophotometer (Model 7225) was used.

One way ANOVA was applied to test the significance of temporal/monthly/seasonal and spatial (upstream to downstream of the river) variation of physicochemical parameters of surface water of Kolpu Khola.

\section{Results and Discussion}

The temperature of leachate decreased from December $\left(19.0^{\circ} \mathrm{C}\right)$ to February $\left(12.5^{\circ} \mathrm{C}\right)$ and then gradually increased to $28.0^{\circ} \mathrm{C}$ in August. The highest chloride content of $3408.00 \mathrm{mg} / \mathrm{l}$ was observed in March (pre-monsoon) and the lowest value of $1988.00 \mathrm{mg} / \mathrm{l}$ was recorded in August. The higher value of chloride has shown the indication of the contamination of domestic organic matter.

The phenolphthalein alkalinity was found to be nil during the entire investigation period and the total alkalinity fluctuated from December $(8300 \mathrm{mg} / \mathrm{l})$ till August $(6500 \mathrm{mg} / \mathrm{l})$. Both BOD and COD of leachate in all the four months had value above generic standard for industrial effluent, $2003(100 \mathrm{mg} / \mathrm{l}$ for BOD and $250 \mathrm{mg} / \mathrm{l}$ for COD). The values of BOD and COD of leachate recorded during the study period were far less than those recorded by ENPHO in February, 2007 (BOD of $29750 \mathrm{mg} / \mathrm{L}$ and COD of $65500 \mathrm{mg} / \mathrm{l}$ ) indicating that the chemistry of leachate in the landfill had undergone rapid change. 


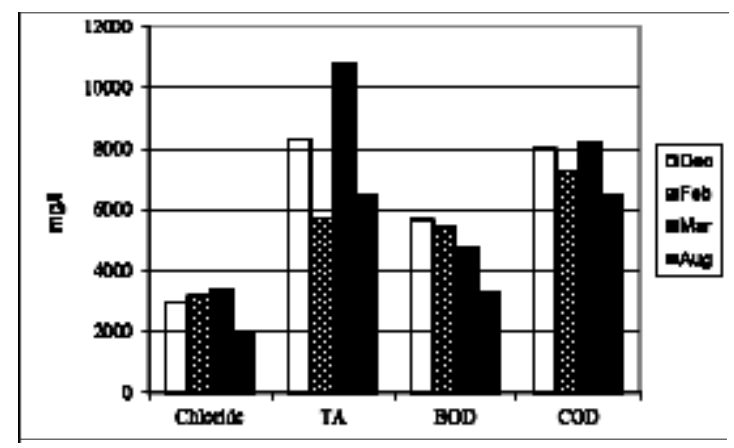

Fig. 2. Monthly variation of chloride, total alkalinity, BOD and COD content of leachate

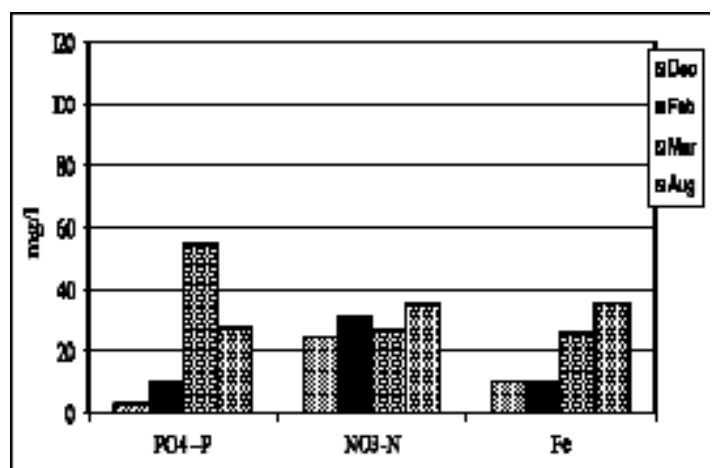

Fig. 3. Monthly variation of orthophosphate, nitrate-nitrogen and iron content of leachate

The hardness of leachate gradually increased from December $\left(1360 \mathrm{mg} / \mathrm{l}\right.$ as $\mathrm{CaCO}_{3}$ ) till August $(5200 \mathrm{mg} /$ 1 as $\mathrm{CaCO}_{3}$ ). The ammoniacal nitrogen content of leachate observed was far above the Generic standard $(50 \mathrm{mg} / \mathrm{l})$ except on August. The slow leaching of nitrogen from solid waste in landfills, resulting in high concentrations of ammonia in the landfill leachate, may last for several decades. The removal of nitrogen from leachate is desirable as nitrogen can trigger eutrophication in lakes and rivers (Jokela et al. 2002)

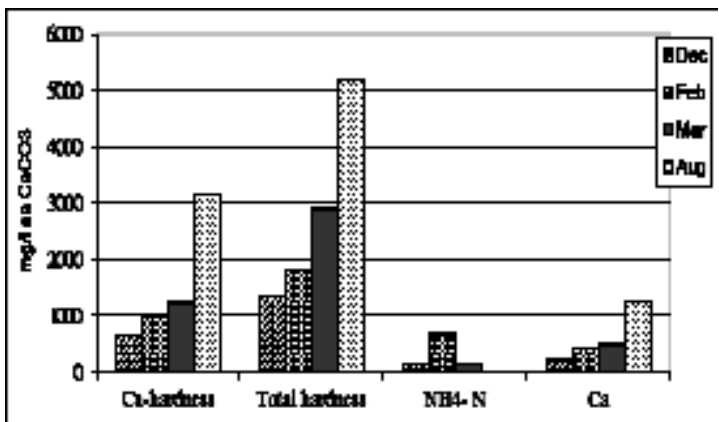

Fig. 4. Monthly variation of calcium hardness, total hardness, ammoniacal- nitrogen and calcium content of leachate
It was found that leachate was severely polluted with some of the physicochemical parameters being higher than the generic standard (2003) for industrial (wastewater) effluents discharged into inland surface water. The physicochemical parameters of the leachate that exceeded the tolerance limit for industrial effluent were BOD, COD and ammoniacal- nitrogen.

The seasonal variation in surface water temperature is significant at 0.01 significance level (two-tailed).

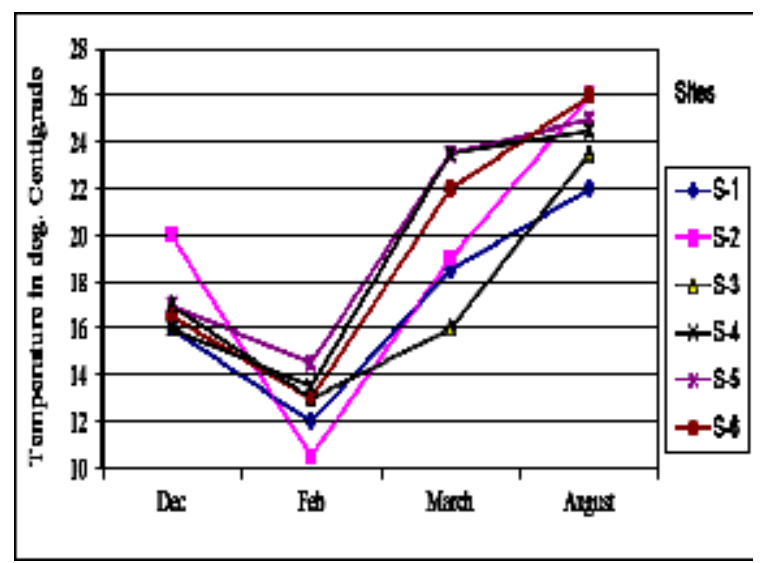

Fig. 5. Monthly variation of water temperature of Kolpu Khola

The $\mathrm{pH}$ of the river water observed from 6.7 to 7.6 throughout the investigation period.

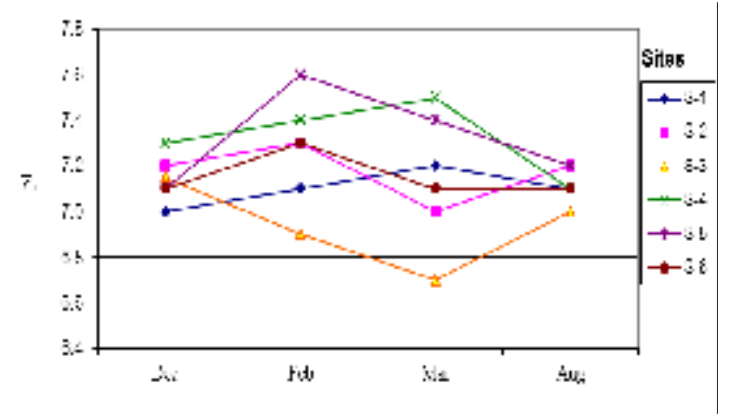

Fig. 6. Monthly variation of $\mathrm{pH}$ of Kolpu Khola

The average electrical conductivity of surface water of the river fluctuated from sites 1 to 4 and then decreased up to site 6 along the river. Conductivity in streams and rivers is affected primarily by the geology of the area through which the water flows. Discharges to streams can change the conductivity depending on their make-up. A failing sewage system would raise the conductivity because of the presence of chloride, phosphate, and nitrate; an oil spill would lower the conductivity. 


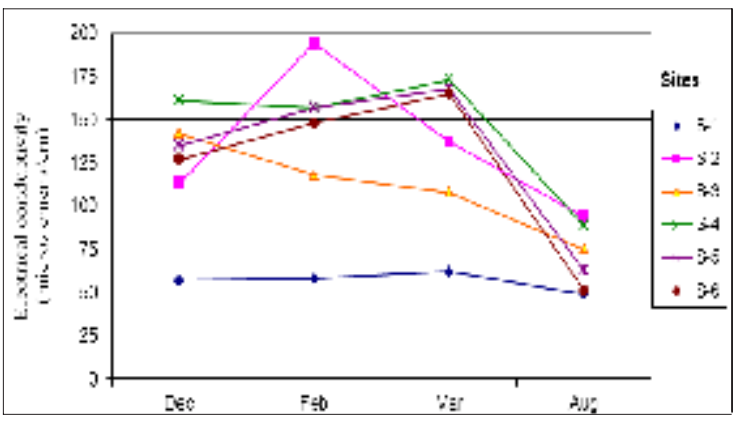

Fig. 7. Monthly variation of Electrical conductivity of Kolpu Khola

The total alkalinity fluctuated from site 1 to site 5 in December, March and August except from site 2 to 3 on March. Alkalinity in itself is not harmful to human beings; still the water supplies with less than 100 $\mathrm{mg} / \mathrm{l}$ alkalinity are desirable to domestic use (Trivedy and Goel 1986).

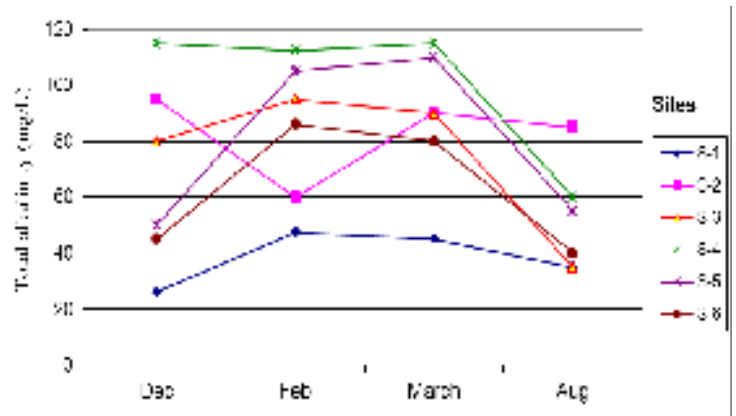

Fig. 8. Monthly variation of total alkalinity of Kolpu Khola

The dissolved oxygen obtained in the surface water was found to be more than those obtained on December at the respective sites. This may be due to decrease in temperature from December to February. In general, the dissolved oxygen content of the river water increased from site 2 to 4 .

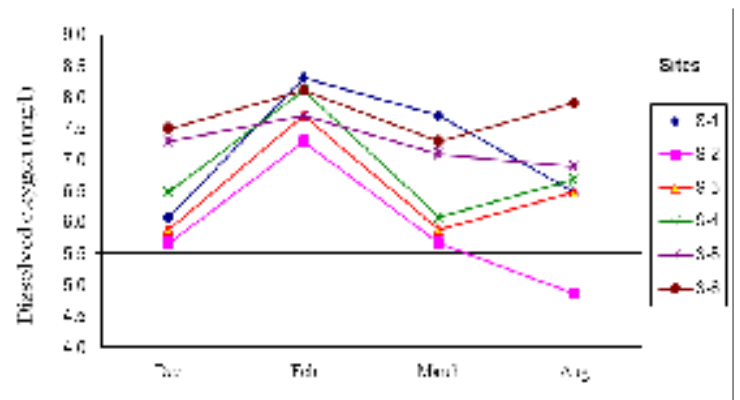

Fig. 9. Monthly variation of dissolved oxygen of Kolpu Khola
The surface water along the Kolpu Khola had the chloride content far below the WHO and NDWQS (National Drinking Water Quality Standard) 2062 (250 $\mathrm{mg} / \mathrm{l})$. Therefore the water was not polluted from chloride point of view. The spatial variation of chloride content was significant at 0.01 significance level. Chloride $\left(\mathrm{Cl}^{-}\right)$is completely soluble and very mobile. It is toxic to aquatic life and impacts vegetation and wildlife. There is no natural process by which chlorides are broken down, metabolized, taken up, or removed from the environment.

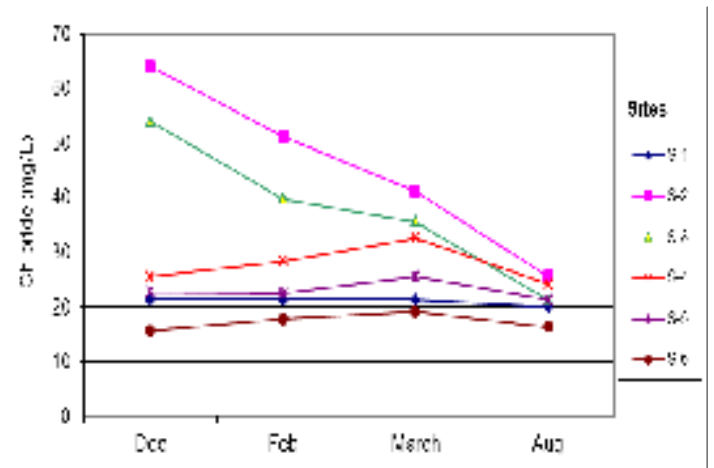

Fig. 10. Monthly variation of chloride content of Kolpu Khola

The hardness at sites 1, 2, 4, 5 and 6 increased from December $\left(16 \mathrm{mg} / \mathrm{l}\right.$ as $\mathrm{CaCO}_{3}$ at station $1,60 \mathrm{mg} / \mathrm{l}$ as $\mathrm{CaCO}_{3}$ at station $2,70 \mathrm{mg} / \mathrm{l}$ as $\mathrm{CaCO}_{3}$ at site $4,64 \mathrm{mg} /$ 1 as $\mathrm{CaCO}_{3}$ at site 5 and $56 \mathrm{mg} / \mathrm{l}$ as $\mathrm{CaCO}_{3}$ at site 6) till February. The observed monthly variation of hardness is significant at 0.05 significance level whereas the observed spatial variation of hardness from site 1 to 6 is significant at 0.01 and 0.05 significance levels.

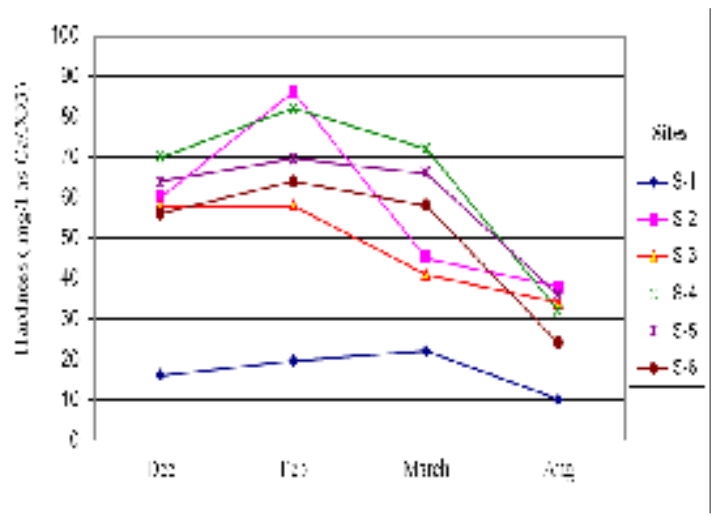

Fig. 11. Monthly variation of hardness of Kolpu Khola 
The pattern of variation of calcium content was similar to that of calcium hardness because calcium hardness is due to the presence of calcium and they have linear relationship (APHA 1995). The greatest contributor of calcium in the Kolpu Khola is the leachate as evident from the leachate quality (Fig. 4)

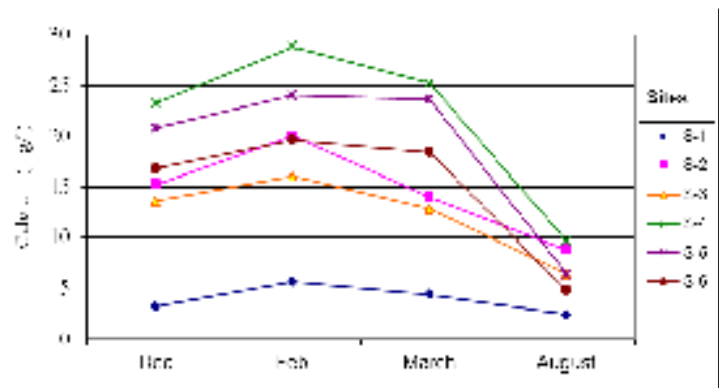

Fig. 12. Monthly variation of calcium content of Kolpu Khola

BOD and COD of the river water increased from site 1 to site 2 throughout the study period. This may be due to the high organic matter and nutrients present in the leachate. After then both BOD and COD decreased to site 6 (downstream). This may be due to natural purification of water. The observed spatial variation of $\mathrm{BOD}$ and $\mathrm{COD}$ is significant at 0.01 significance level.

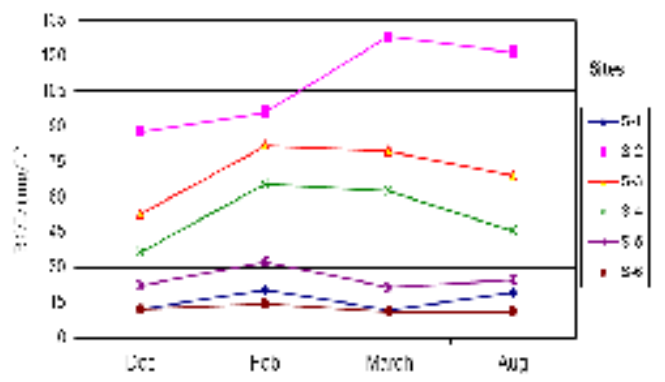

Fig. 13. Monthly variation of biological oxygen demand content of Kolpu Khola

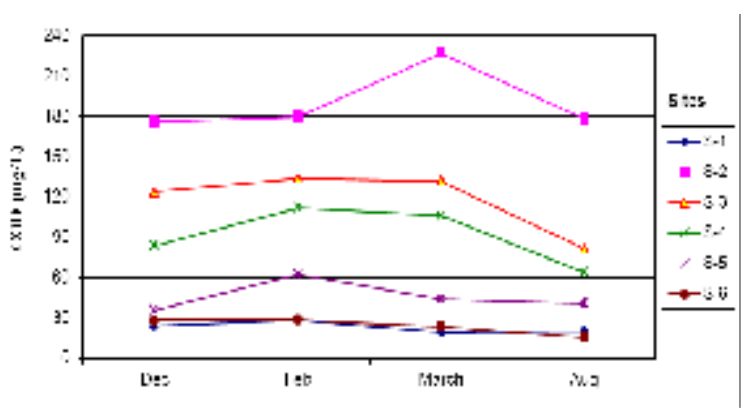

Fig. 14. Monthly variation of chemical oxygen demand content of Kolpu Khola
Natural concentrations of phosphorus in surface waters usually range from 0.005 to $0.020 \mathrm{mg} / \mathrm{l}$. (Chapman 1996). Since the water of all the sites have the $\mathrm{PO}_{4}-\mathrm{P}$ above this range, the river had $\mathrm{PO}_{4}-\mathrm{P}$ beyond the natural condition probably because of washing and bathing in the river from upstream to downstream or the fertilizer run-off from the agricultural field. Phosphorus occurs naturally in rocks, soil, animal waste, plant material, and even the atmosphere. In addition to these natural sources, phosphorus comes from human activities such as agriculture, discharge of industrial and municipal waste, and surface water runoff from residential and urban areas. Nutrients held in soil can be dissolved in water and carried off by leaching, tile drainage or surface runoff (CCME 2009). These phosphates become detrimental when they over fertilize aquatic plants and cause stepped up eutrophication.

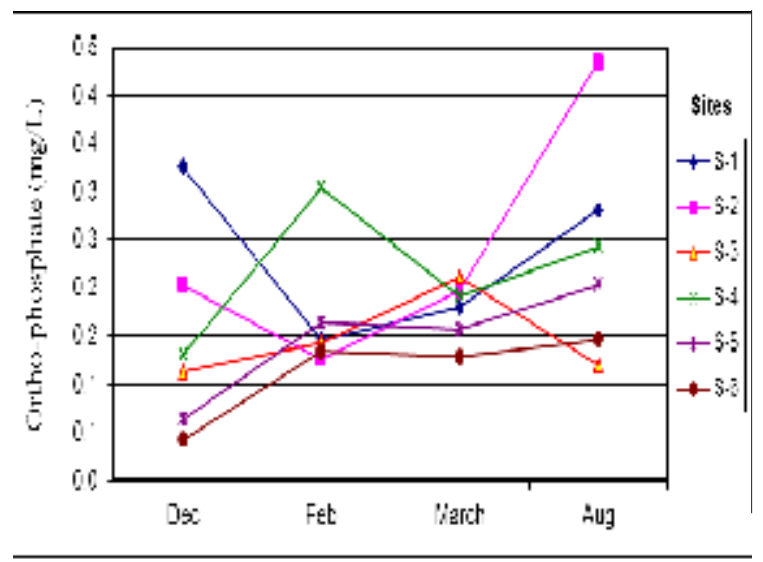

Fig. 15. Monthly variation of orthophosphate content of Kolpu Khola

Nitrogen is very common and found in many forms in the environment. Inorganic forms include nitrate $\left(\mathrm{NO}_{3}\right)$, nitrite $\left(\mathrm{NO}_{2}\right)$, ammonia $\left(\mathrm{NH}_{3}\right)$, and nitrogen gas $\left(\mathrm{N}_{2}\right)$. Nitrate is the common form of combined nitrogen found in natural waters as it is highly soluble (dissolves easily) in water and is stable over a wide range of environmental conditions. It is easily transported in streams and groundwater. The concentration of nitrate could be used as an important indicator for organic pollution of water (Singh et al. 2013). The nitratenitrogen content of the river water varied from 0.32 to $3.20 \mathrm{mg} / \mathrm{l}$ which was far below the WHO (1993) and NDWQ standard $2062(50 \mathrm{mg} / \mathrm{l})$. The observed monthly variation of nitrate-nitrogen content is significant at 0.01 significance level. 
Ujjwal Thapa Shrestha et al./Assessment of Water Quality ......

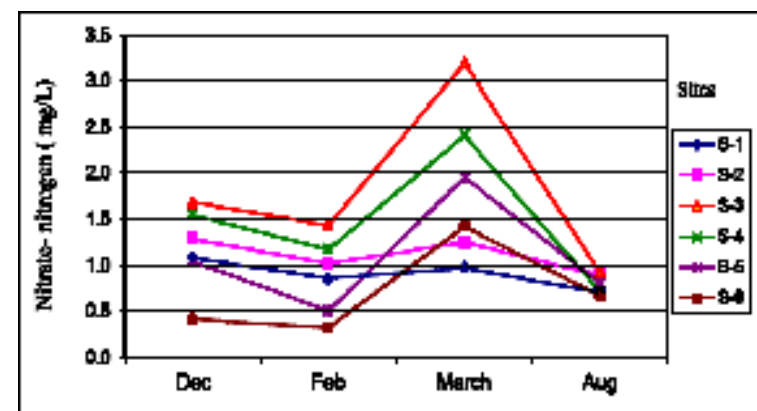

Fig. 16. Monthly variation of nitrate- nitrogen content of Kolpu Khola

Ammonia is present naturally in surface waters. It is produced largely by deamination of organic nitrogen containing compounds and by hydrolysis of urea (APHA 2005). Ammonia ( $\mathrm{NH}_{3}$ ) occurs naturally in water bodies as a result of the breakdown of organic and inorganic matter in soil and water, excretion from biota, and reduction of atmospheric nitrogen by microorganisms. Also, some industrial processes discharge ammonia products. In an aqueous solution, un-ionized ammonia exists in equilibrium with the ammonium ion, the distribution of forms depending upon $\mathrm{pH}$. Total ammonia is the sum of unionized and ammonium forms. Total ammonia concentrations in surface waters are typically less than $0.2 \mathrm{mg} / \mathrm{l}$ but may reach 2-3 mg/l (Chapman 1996). Higher concentrations could be an indicator of pollution such as domestic sewage, industrial waste, or fertilizer runoff. The increase in ammoniacal-nitrogen content from site 1 to 2 was probably because the river received leachate containing organic nutrient with low or no oxygen content that caused ammonification of nitrogenous materials of the leachate. It may also be due to fertilizer runoff received from nearby agricultural land as there were no visible sources of domestic sewage or industrial waste discharged into the river. Such spatial variation of ammoniacal nitrogen content is significant at 0.01 significance level.

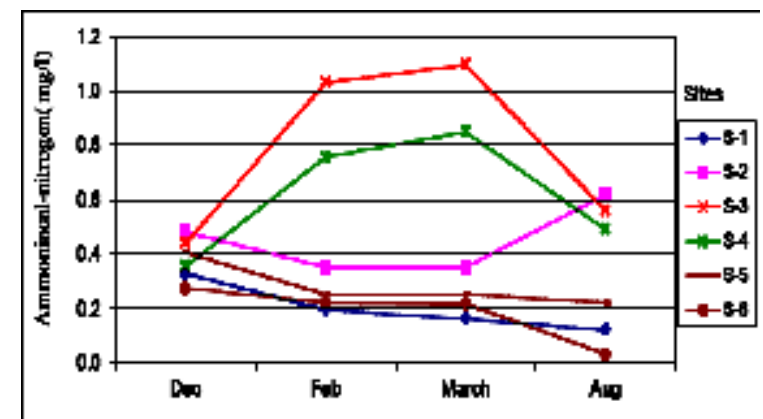

Fig. 17. Monthly variation of ammoniacal nitrogen content of Kolpu Khola
Except site 2 the surface water of all other five sites are safe for aquatic life from point of view of dissolved oxygen only as the CCME (1999) Water Quality Guidelines is 5.5 to $9.5 \mathrm{mg} / \mathrm{l}$ for dissolved oxygen. Throughout the study period the iron content fluctuated from 0.15 to $4.05 \mathrm{mg} / \mathrm{l}$. Iron content of surface water at all sites except site 3 in December and February exceed $0.3 \mathrm{mg} / \mathrm{l}$ (CCME 1999). Hence all the surface waters are unsuitable for freshwater aquatic life from point of view of iron. Surface water of Kolpu Khola under study is excellent for irrigation from conductivity point of view and is generally safe for all plants when used for irrigation from the chloride point of view. The river water is safe for livestock drinking from point of view of $\mathrm{pH}$, alkalinity, nitrate- nitrogen and chloride.

The physicochemical parameters such as $\mathrm{pH}$, chloride, hardness, calcium and calcium hardness, BOD, COD and ammoniacal nitrogen vary significantly from site 1 to site 6 whereas only the monthly variations of temperature, electrical conductivity, hardness, calcium and calcium hardness and nitrate-nitrogen were significant over the investigation period. Most of the parameters of surface water of Kolpu Khola showed sudden increase in values at site 2 i.e. point of discharge of leachate compared to site 1 (upstream) probably due to mixing of pollutants present in the leachate. However the discharge of leachate from the landfill is not uniform throughout the study period.

The physicochemical parameters of the leachate that exceeded the tolerance limit for industrial effluent were BOD, COD and ammoniacal- nitrogen. The hardness of leachate gradually increased from December (1360 $\mathrm{mg} / \mathrm{l}$ as $\mathrm{CaCO}_{3}$ ) till August (5200 mg/l as $\mathrm{CaCO}_{3}$ ). The less values of BOD and COD of leachate compared to those recorded in previous studies indicated that the chemistry of leachate in the landfill was undergoing rapid change. The physicochemical parameters such as $\mathrm{pH}$ chloride, hardness, calcium and calcium hardness, BOD, COD and ammoniacal nitrogen varied significantly from station site 1 to site 6 . The $\mathrm{pH}$ of the river water observed from 6.7 to 7.6 throughout the investigation period. The water was not polluted from chloride point of view and the spatial variation of chloride content was significant at 0.01 significance level. The surface water of all the sites had the $\mathrm{PO}_{4}-\mathrm{P}$ above natural range i.e. 0.005 to $0.020 \mathrm{mg} / \mathrm{l}$. The increase in ammoniacal nitrogen content from site 1 to 2 was probably because the river received leachate 
Nepal Journal of Science and Technology Vol. 15, No.1 (2014) 107-114

containing organic nutrients with low or no oxygen content that caused ammonification of nitrogenous materials of the leachate. The river water was safe for livestock drinking from point of view of $\mathrm{pH}$, alkalinity, nitrate- nitrogen and chloride. The surface water of Kolpu khola at the sites under study was not suitable for fishes and other aquatic animals from the point of view of most of the physicochemical parameters. The river water was not safe for livestock drinking.

\section{Acknowledgements}

My sincere gratitude goes to my Supervisor Prof. Jaya Krishna Shrestha, Central Department of Chemistry, Tribhuvan University and Co-supervisor Mr. Rohini Prasad Devkota, Central Department of Environmental Science for their continuous guidance, meticulous support and constant encouragement throughout the study during the present research work. My heartly thanks also go to Prof. Dr. Hridaya Bahadur Shrestha, Central Department of Statistics, TU for helping in statistical analysis of the data. The financial support provided by the Solid Waste Management and Resource Mobilization Centre, Pulchowk, Lalitpur for conducting this study is highly acknowledged.

\section{References}

APHA/AWWA/WEF. 1995. Standard methods for the examination of water and waste water, $19^{\text {th }}$ Edition. American Public Health Association, American Water Works Association, Water Pollution Control Federation. Published by the American Public Health Association, Washington DC, USA.

APHA/AWWA/WEF. 2005. Standard methods for the examination of water and waste water, $21^{\text {st }}$ Edition. American Public Health Association, American Water Works Association, Water Pollution Control Federation. Published by the American Public Health Association, Washington DC, USA.

CCME. 1999. Canadian Council Ministries of Environment (1999) Surface Water Quality Guidelines for Use in ALBERTA, November 1999; Environmental Assurance Division Science and Standards Branch, Alberta Environment, Edmonton, Alberta. 8pp.

CCME. 2009. Canadian Council Ministries of Environment Source to Tap: Phosphorus Available at: http:// www.ccme.ca/sourcetotap/phosphorus.html Year of posting April 15, 2009

Chapman, D. 1996. Water quality assessments - A guide to use of biota, sediments and water in environmental Monitoring, Second Edition, Published on behalf of
UNESCO, World Health Organization, United Nations Environment Programme, University, London. 91pp

ENPHO. 2007. Surface water, groundwater and leachate quality monitoring at Sisdol Semi-aerobic landfill Site. Submitted to Solid Waste Management and Resource Management Centre (SWMRMC), Ministry of Local Development (MOLD), Lalitpur.

HMG/MOPE. 2003. Nepal Gazette, generic standard: tolerance limit for industrial (Wastewater) effluents discharged into inland surface water.

JICA. 2004. Detailed design for development of Semi-aerobic system pilot project at Sisdol landfill Site, Lalitpur, Nepal: East Consult. (P.) Ltd.

Jokela, J. P. Y., R. H. Kettunen, K. M. Sormunen and J. A. Rintala. 2002. Biological nitrogen removal from municipal landfill leachate: low-cost nitrification in biofilters and laboratory scale in-situ denitrification. Water Research 36 (16): 4079-4087

Kouzeli-Katsiri, A., A. Bosdogiannia and D. Christoulas. 1999. Prediction of leachate quality from sanitary landfills. Journal of the Environmental Engineering Division 125 (10): 950-958.

Leckie J. O., J. G. Pacey and C. Halvadakis. 1979. Landfill management with moisture control. Journal of the Environmental Engineering Division 105 (2): 337-355.

Miller, G. T. 2002. Living in the environment. Wadsworth Publishing Company, Belmont, California.

NDWQS. 2062BS. National drinking water quality standard 2062 and national drinking water quality guidelines 2062. Nepal Government, Ministry of Physical Planning and Works. [Translated in Nepali]

OECD. 2008. Glossary of Statistical Terms. OECD publications, France. 503pp.

Singh, S., J. Harjit, H. C. Kataria and S. Amlathe. 2013. Determination of nitrate in polluted water with new coupling reagent hydroxamic acids : A rapid and high potential reagent for trace determination of nitrate in polluted water. journal of Environment and Earth Science (Online) 3 (6): 9- 17.

SWMRMC. 2005. Environmental impact assessment for solid waste treatment plant and development of sanitary landfill site at Sisdol-ko-Gairo, Okharpauwa VDC, Nuwakot. SWMRMC, MoLD/HMG, Shreemahal, Pulchowk, Lalitpur.

Trivedy, R. K. and P. K. Goel. 1986. Chemical and biological methods for water pollution studies. Environmental Publication, Karad 415110, India.

UNEP. 1999. Global environment outlook 2000. Division of Environmental Information, Assessment and Early Warning (DEIA \& EW), United Nations Environment Programme, Nairobi, Kenya. 7 pp.

WHO. 1993. Guidelines for Drinking water quality. Vol. 1 Recommendations, $2^{\text {nd }}$ edition, World Health Organization, Geneva, Switzerland. 